\title{
Morphodynamic changes in a natural river confluence due to a hydropower modified flow regime
}

\author{
M. Leite Ribeiro \\ Stucky SA, Renens, Switzerland \\ S. Wampfler \\ Basel, Switzerland \\ A.J. Schleiss \\ Laboratory of Hydraulic Constructions ( LCH), Ecole Polytechnique Fédérale de Lausanne (EPFL), \\ Lausanne, Switzerland
}

\begin{abstract}
River channel confluences form important morphological components of any river system. This article presents the results of an investigation on a natural river confluence in Switzerland. The aim of the field work performed at the confluence of the Sarine (main channel) and Gerine (tributary) Rivers near Fribourg $(\mathrm{CH})$ is to analyze the interaction between morphological processes on the confluence and hydropower-affected hydrology of the main River. Important morphological changes have been observed over the last years, especially the deflection of the Sarine River and erosion of the left bank opposite of the tributary. Numerical calculations have shown that currently the minimal discharge of the Sarine River which transports the sediments annually deposited at the confluence is attained on average once each 2 years. Before the construction of the Rossens Dam, the minimum discharge was reached every year. This lack of yearly floods with sediment mobilization can explain the morphological changes occurred at the confluence since the construction of the dam.
\end{abstract}

\section{INTRODUCTION}

River confluences are the nodes of the fluvial network. They are zones where an important interaction between flow dynamics, sediment transport and bed morphology occurs (Best, 1988, Boyer et al., 2006, Rhoads et al. 2009). The interplay between sediment loads and the discharges in the tributary and the main channel appears to be the critical factor governing confluence morphology (Leite Ribeiro et al. 2012a,b).

Confluence hydrodynamic zones (CHZ), i.e., the zones around the confluence affected by the flow convergence (Kenworthy and Rhoads, 1995) are critical points with respect to the lateral and longitudinal connectivity of the network. It may represent biological hotspots in river networks (Benda et al., 2004; Rice et al., 2008) as in natural conditions they are typically characterized by high habitat heterogeneity, high variability in flow, sediment load, sediment size. These are requisites for high quality fluvial ecosystems.

This article presents a field investigation performed at the natural river confluence between the Sarine (main) and Gerine (tributary) Rivers near Fribourg (Switzerland). The morphology of the confluence has been affected by a significant change in the flow regime of the main river due to the implementation of a storage hydropower scheme some kilometers upstream. The objective of the study is to analyze the morphological changes occurred in this confluence since the construction of the Rossens Dam. The analysis has been done based on historical maps of the confluence, as well as a field investigation performed in 2008. The study 
has been completed by a simplified two-dimensional numerical study, where the objective was to determine the threshold conditions for the sediment transport at the confluence.

\section{SARINE-GERINE CONFLUENCE}

The confluence of the Sarine (main) and Gerine (tributary) Rivers is illustrated in Figure 1. This confluence is one of the rare confluences in Switzerland that is still in its natural condition, i.e. without any engineering intervention on the $\mathrm{CHZ}$.

A three-dimensional representation of the Gerine and the Sarine Rivers upstream of their confluence is represented in Figure 2.

\subsection{The Gerine River}

The source of the Gerine River (drainage area of $79 \mathrm{~km}^{2}$ ) is on the Massif de la Berra at elevation 1500 masl, around $20 \mathrm{~km}$ upstream of the confluence. The Gerine is a torrential river, with bed slopes varying from $1.6 \%$ at the mouth to $46 \%$ at Berra. The streams feeding the Gerine are very short and their slopes are always higher than 6\%.

Along its course, the Gerine River is subjected to alternating deficit and excess of sediments. In the upstream reach, the river behaves as a torrent with an erosion regime. There is an

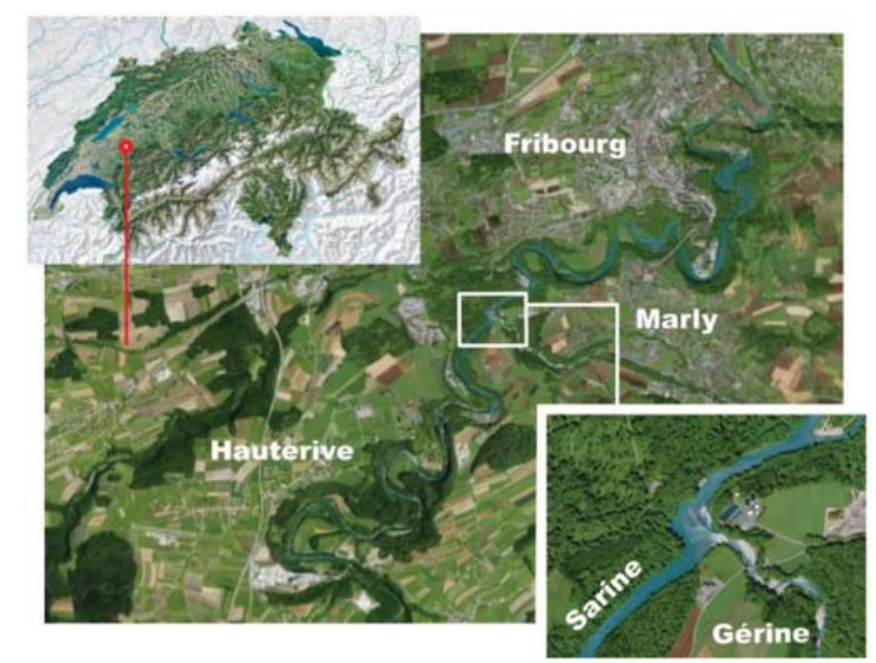

Figure 1. Location of the Sarine-Gerine confluence in Switzerland.

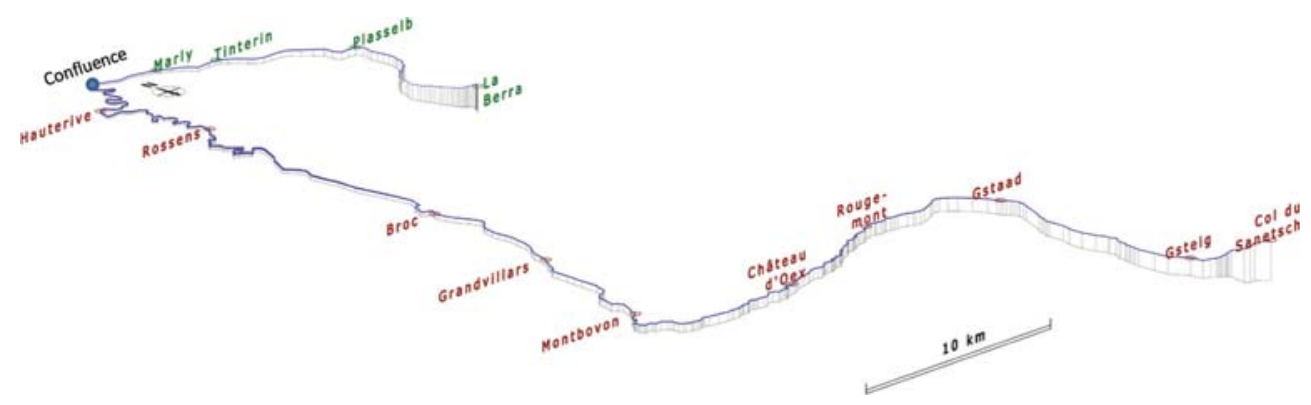

Figure 2. Three-dimensional representation of the Sarine and Gerine Rivers upstream of their confluence. 
erosion zone at Plasselblund that is followed by an alluvial cone at Sagenboden. The sequence erosion zone-alluvial cone is repeated between Tinterin and the confluence. The annual volume of sediments transported to the confluence is around $40^{\prime} 000 \mathrm{~m}^{3}$ (Wampfler, 2008).

\subsection{The Sarine River}

The Sarine River rises at Sanetsch, at elevation 2252 masl. The length of the river until the confluence with the Gerine is about $85 \mathrm{~km}$ (surface of the river basin $981 \mathrm{~km}^{2}$ ). The river has a very irregular bed slope, varying from a near-vertical profile at the Sanetsch Dam and a bed slope of $0.45 \%$ near the confluence.

There are several dams constructed along its course, which influences the sediment transport along the river. The largest one is the Rossens Dam, located around $15 \mathrm{~km}$ upstream of the confluence. The artificial lake created by the Rossens Dam works as huge sediment retaining reservoir. Downstream of the dam, the sediment input and transport is very limited until the confluence.

\subsection{Hydrology}

The flood peak discharges of the confluents are presented in Table 1. For the Gerine River, the values are based on the gauging station located at Marly some kilometers upstream of the confluence (drainage area at the station $=77.6 \mathrm{~km}^{2}$ ). In the case of the Sarine River, a hydrological analysis has been made based on the fluvial gauging stations located at Broc (around $32 \mathrm{~km}$ upstream of the confluence), Fribourg (around $10 \mathrm{~km}$ downstream) and Laupen (around $28 \mathrm{~km}$ downstream).

\subsection{Rossens Hydropower Scheme}

Figure 3 presents an overview of the Rossens Hydropower Scheme. The lake created by the Rossens Dam (arch dam $83 \mathrm{~m}$ high) is called Lake of Gruyère and has a surface of $9.4 \mathrm{~km}^{2}$ and a volume of 200 million $\mathrm{m}^{3}$. This is the longest artificial lake in Switzerland.

Table 1. Flood discharges of the Gerine and Sarine Rivers at the confluence.

\begin{tabular}{lrrrrrrrr}
\hline $\mathrm{T}$ (years) & 1 & 2 & 5 & 10 & 20 & 50 & 100 & 200 \\
\hline$Q\left(\mathrm{~m}^{3} / \mathrm{s}\right)$ & & & & & & & & \\
Gerine & 56 & 68 & 82 & 92 & 103 & 117 & 127 & 138 \\
Sarine & 84 & 250 & 352 & 414 & 464 & 524 & 565 & 602 \\
\hline
\end{tabular}

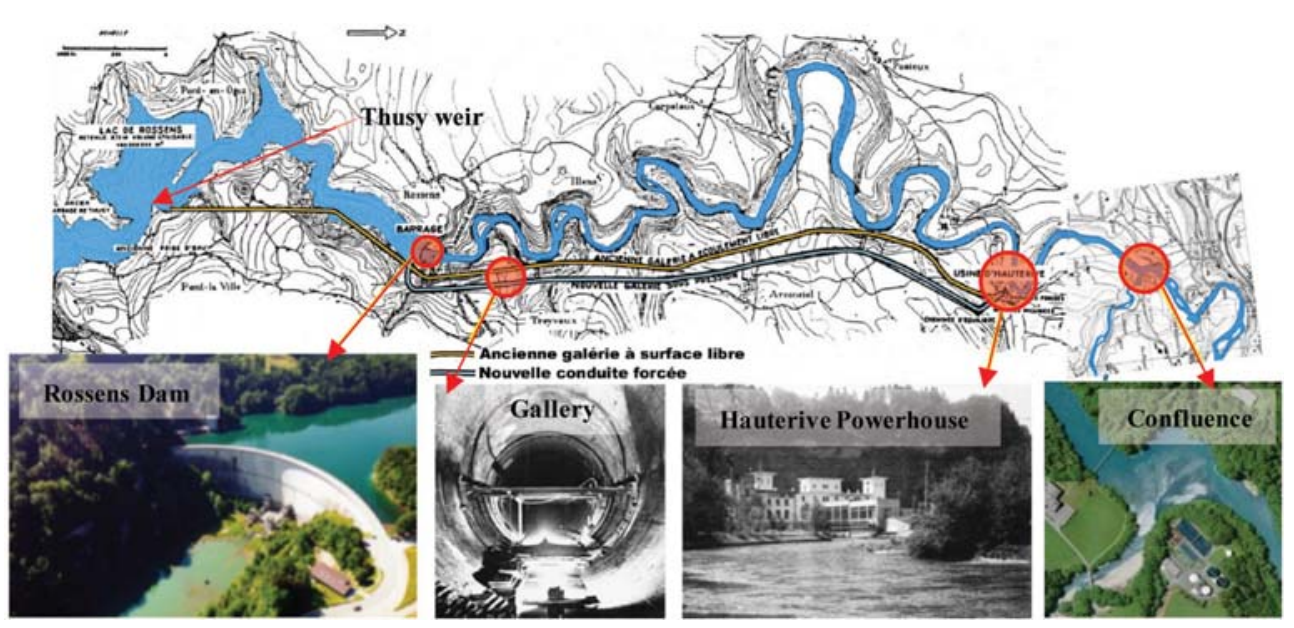

Figure 3. Rossens Hydropower Scheme. 
The Hauterive Powerhouse is located between the Dam (13.5 km upstream) and the confluence $(1.5 \mathrm{~km}$ downstream). The plant is connected with the lake by a circular gallery approximately $6 \mathrm{~km}$ long constructed at the right bank. The maximum discharge through the gallery is $75 \mathrm{~m}^{3} / \mathrm{s}$. The short-circuit reach between the intake and the powerhouse is called Little Sarine. It is supplied by a residual discharge of $3.5 \mathrm{~m}^{3} / \mathrm{s}$ during the summer and $2.5 \mathrm{~m}^{3} / \mathrm{s}$ during the winter (Mivelaz, 2005). The Little Sarine is not subjected to the hydropeaking effects and therefore this reach plays a vital role in the reproduction of aquatic fauna.

The Hauterive powerhouse was commissioned in 1902 and initially turbined water from the Thusy Dam, located around $3.2 \mathrm{~km}$ upstream of Rossens. Since the construction of the Rossens Dam in 1948, the hydrological regime of the Sarine has changed significantly due to the hydropeaking regime (Fig. 4) and flood routing by the artificial lake upstream of the confluence.

The number of floods and flood magnitudes reduced considerably at the confluence. The average annual peak flow decreased by $120 \mathrm{~m}^{3} / \mathrm{s}$ for the gauging station in Fribourg (Fig. 5).
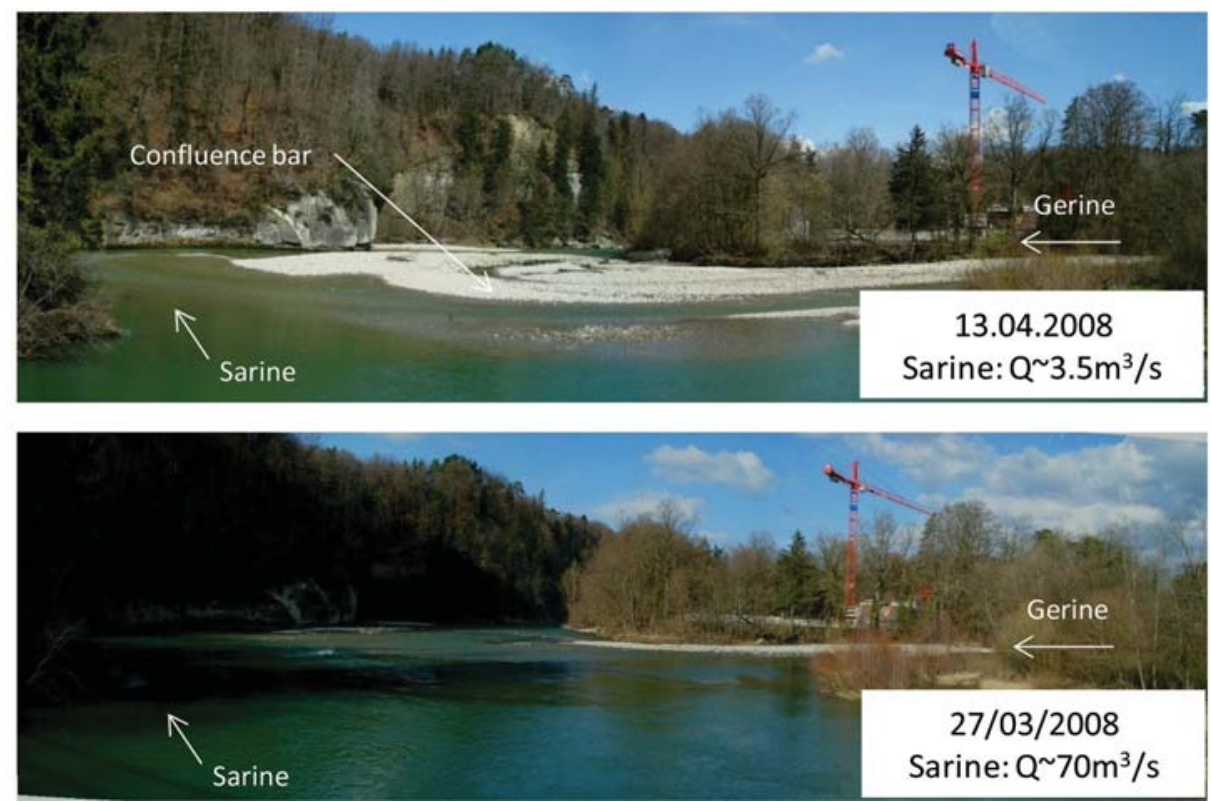

Figure 4. Effect of the hydropeaking on the confluence.

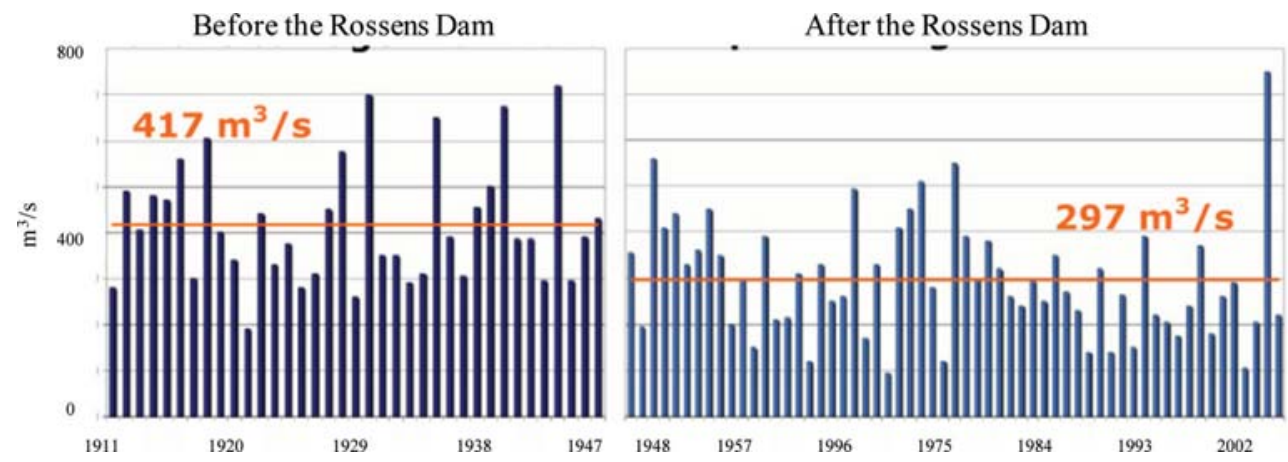

Figure 5. Annual peaks of the Sarine River from 1911 to 2007 in Fribourg (Swiss Federal Office for the Environment, 2007). 
The morphological evolution of the confluence has been analyzed by means of historical and recent maps (Fig. 6). The historical Siegfried Map elaborated in 1945 illustrates the situation before the construction of the Rossens Dam, whereas the Swiss National Maps elaborated in 1974, 1992, 1998 and 2005 present the morphological evolution of the confluence from the construction of the dam. The overlay contours reveals the changes between each period.

It can be noted that the operation of the Rossens Hydropower scheme affected considerably the dynamics of the confluence. Before Rossens Dam, the Sarine regime predominated over the Gerine regime, whereas from 1948, this situation has been reversed.

Between 1945 and 1974 the left bank of the Sarine was completely eroded downstream of the confluence, forming a vertical rocky cliff. Major morphological changes are also visible on the floodplain. The fact that the Gerine course has changed indicates that large floods took place during this period ( 29 years). The construction of a new road bridge crossing the Gerine forced the passage of this river to the left bank.
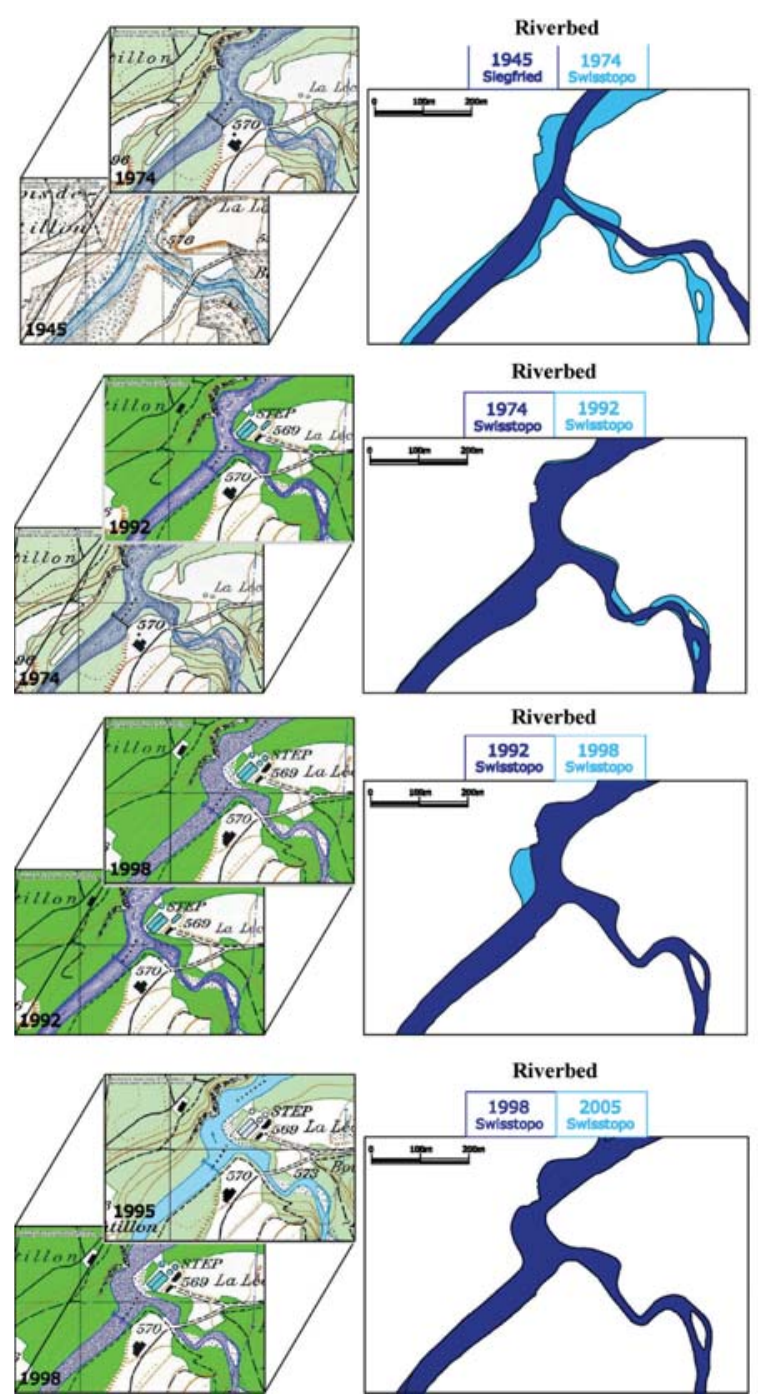

Riverbed

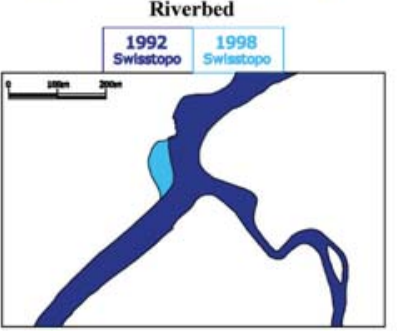

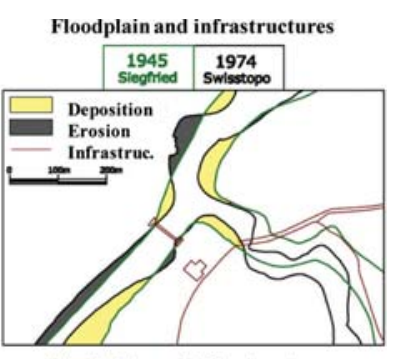

Floodplain and infrastructures

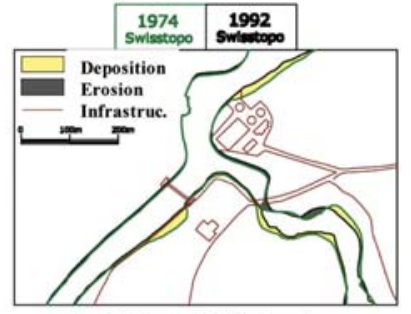

Floodplain and infrastructures

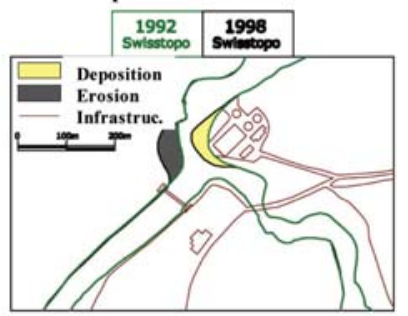

Floodplain and infrastructures

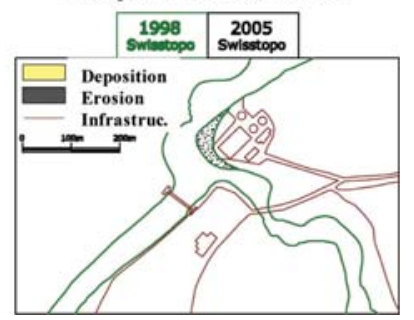

Figure 6. Morphological changes in the confluence zone from 1945 to 2005. 
From 1974 to 1992, the confluence was not subject to significant changes. The erosion of the left bank has slightly increased. The flood of the Sarine in $1977\left(Q=550 \mathrm{~m}^{3} / \mathrm{s}\right)$ had no significant impact on the morphology of the confluence.

The morphological change observed between 1992 and 1998 is very marked. A large area has been eroded on the left bank showing that important differences can occur over a limited time. Between 1992 and 1998, the Sarine has not experienced important floods, able to significantly alter the morphology of the confluence.

The erosion of the left bank between 1992 and 1998 is probably due to floods in the Gerine River occurred in $1995\left(\mathrm{Q}_{\max }=101.8 \mathrm{~m}^{3} / \mathrm{s}\right)$ and on $1997\left(\mathrm{Q}_{\max }=147.7 \mathrm{~m}^{3} / \mathrm{s}\right)$. The 1997's flood has a return period larger than 200 years.

Between 1998 and 2005, the morphology of the confluence remained unchanged. The 2005 's flood occurred in the Sarine has resulted in a maximum of $680 \mathrm{~m}^{3} / \mathrm{s}$. The flow of the Sarine was probably sufficient to evacuate the material transported by the Gerine.

\section{TWO-DIMENSIONAL NUMERICAL SIMULATIONS}

Simplified hydrodynamic numerical simulations have been performed with CCHE2D, a twodimensional depth-averaged model developed by the National Center for Computational Hydroscience and Engineering of the University of Mississipi, USA. The objective of the simulations performed under steady flow conditions with fixed bed and without sediment transport is to determine the minimum discharge of the Sarine River, which is able to transport the sediments deposited at the confluence.

\subsection{Basic data}

\subsubsection{Bathymetry}

Most of the bathymetry of the confluence used for the simulations has been surveyed in 2000 (Ribi, 2000). This bathymetry has been completed by a simplified survey of the confluence bar performed in 2008. Figure 7 presents the bathymetry used for the simulations.

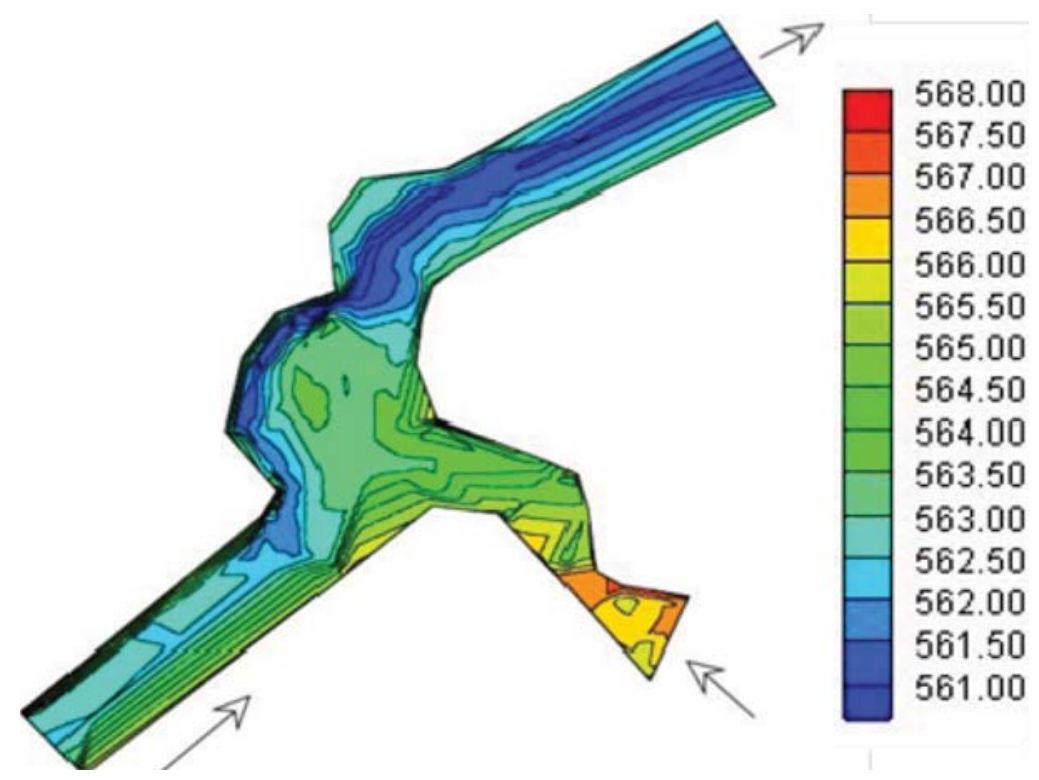

Figure 7. Bathymetry of the confluence used for the numerical simulations. Color bars represent the bed elevation (masl). 


\subsubsection{Grain size characteristics}

The grain size characteristics of the Sarine and the Gerine Rivers are presented in Table 2. The characteristics of each river have been determined following the Linear Sampling Method proposed by Fehr (1987).

\subsection{Methodology}

In order to assess the sediment transport behaviour at the confluence, 7 scenarios with different combinatios between the Sarine and Gerine discharges have been considered (Table 3). The analysis has been performed by comparing the driving forces of particle motion (shear stress) to the resisting forces that would make it stationary (particle density and size). For that comparison, the Shields Diagram (Shields, 1936) has been used.

\subsection{Results}

In the confluence zone, the dimensionless diameter $\mathrm{d}_{*}$ calculated according to Shields (Equation 1) is equal to 1'264. It means that the flow is in the rough turbulent regime and the critical dimensionless shear stress $t_{*_{\mathrm{cr}}}$ can be adopted as 0.047 . Therefore, the critical shear stress $\tau_{\mathrm{cr}}$ (Equation 2) is around $46 \mathrm{~N} / \mathrm{m}^{2}$.

$$
d_{*}=d\left(\frac{\rho_{s}-\rho}{\rho} * \frac{g}{v^{2}}\right)^{\frac{1}{3}}
$$

where $d^{*}=$ dimensionless diameter, $d(\mathrm{~m})=$ characteristic particle diameter of the sediment, $\rho_{\mathrm{s}}\left(\mathrm{kg} / \mathrm{m}^{3}\right)=$ density of the sediment, $\rho\left(\mathrm{kg} / \mathrm{m}^{3}\right)=$ density of the water, $g\left(\mathrm{~m} / \mathrm{s}^{2}\right)=$ acceleration due to gravity and $v\left(\mathrm{~m}^{2} / \mathrm{s}\right)=$ kinematic viscosity.

$$
\tau_{c r}=\tau_{*}\left(\gamma_{s}-\gamma\right) \mathrm{d}
$$

where $\tau_{\text {cr }}=$ critical shear stress $\left(\mathrm{N} / \mathrm{m}^{2}\right), t_{*}=$ critical dimensionless shear stress, $\gamma_{\mathrm{s}}\left(\mathrm{N} / \mathrm{m}^{3}\right)=$ specific weight of the sediment, $\gamma\left(N / \mathrm{m}^{3}\right)=$ specific weight of the water and $d(\mathrm{~m})=$ characteristic particle diameter of the sediment.

Table 2. Grain size characteristics of the sediments found in the Sarine and the Gerine Rivers.

\begin{tabular}{lllll}
\hline River & $\mathrm{d}_{\mathrm{m}}(\mathrm{cm})$ & $\mathrm{d}_{50}(\mathrm{~cm})$ & $\mathrm{d}_{90}(\mathrm{~cm})$ & Source \\
\hline Gerine & 9 & 6 & 22 & Jaeggi, 1999 \\
Sarine & 5 & 3 & 10 & Wampfler, 2008 \\
\hline
\end{tabular}

Table 3. Simulated hydraulic scenarios.

\begin{tabular}{lll}
\hline Scenario & $Q_{\text {Sarine }}$ & $Q_{\text {Gerine }}$ \\
\hline 1 & $Q_{1}=84 \mathrm{~m}^{3} / \mathrm{s}$ & $Q_{1}=56 \mathrm{~m}^{3} / \mathrm{s}$ \\
2 & $Q=100 \mathrm{~m}^{3} / \mathrm{s}$ & \\
3 & $Q=125 \mathrm{~m}^{3} / \mathrm{s}$ & \\
4 & $Q=150 \mathrm{~m}^{3} / \mathrm{s}$ & $Q=2 \mathrm{~m}^{3} / \mathrm{s}$ \\
5 & $Q=175 \mathrm{~m}^{3} / \mathrm{s}$ & \\
6 & $Q=200 \mathrm{~m}^{3} / \mathrm{s}$ & \\
7 & $Q_{2}=225 \mathrm{~m}^{3} / \mathrm{s}$ & \\
\hline
\end{tabular}


From Figure 8, it can be observed that the critical shear stress is already exceeded for annual floods in the Gerine River upstream of the confluence. Therefore, it suggests that the sediment transport at the Gerine starts from events with peak discharges lower than those corresponding to the annual flood.

By analyzing the influence of the Sarine's discharge on the transport capacity over the confluence bar (line A-B on Figure 9, left), it has been found that critical shear stress of $46 \mathrm{~N} / \mathrm{m}^{2}$ is exceed for peak discharges of the Sarine of around $175 \mathrm{~m}^{3} / \mathrm{s}$. This corresponds to approximately a 2-year return period flood $\left(Q_{2}=250 \mathrm{~m}^{3} / \mathrm{s}\right)$ after the construction of the Rossens Dam. The spatial distribution of the shear stresses for the scenario 5: $Q_{\text {Sarine }}=175 \mathrm{~m}^{3} / \mathrm{s}$ and $Q_{\text {Gerine }}=2 \mathrm{~m}^{3} / \mathrm{s}$ is presented in Figure 9 (right).

Therefore, it seems that the confluence is currently not in equilibrium from the sediment transport point view. There is an imbalance between the frequency of the sediment transport in the Gerine ( $<1$ year) and in the Sarine ( $\sim 2$ years). This imbalance is supposed to be responsible for the main morphological changes occurred in the confluence since the construction of the Dam. The sediments annually transported by the Gerine are deposited in the confluence bar. As it takes on average two years so that the confluence bar can be washed, the obstacle

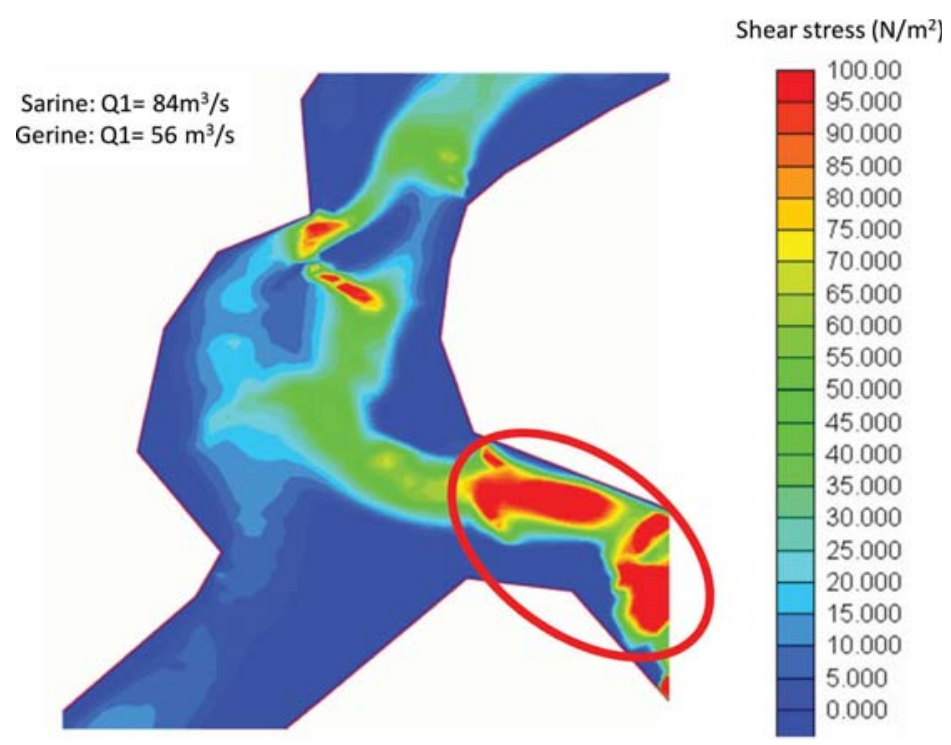

Figure 8. Shear stresses calculated for annual floods at Sarine and at Gerine Rivers.

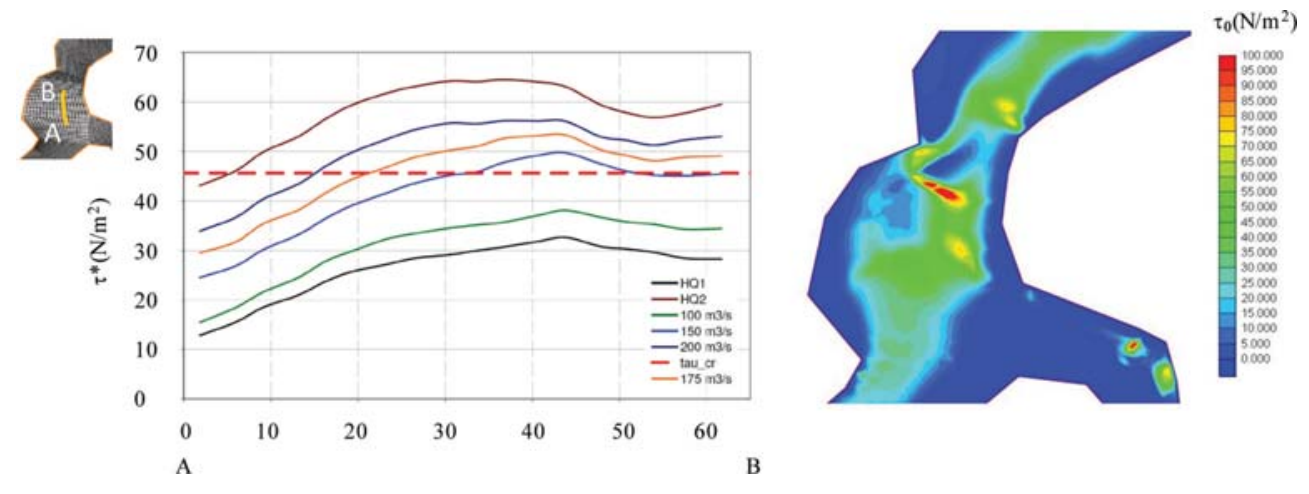

Figure 9. Shear stresses at the confluence bar over the line A-B (left) and spatial distribution of the shear stresses $\left(\mathrm{N} / \mathrm{m}^{2}\right)$ on the confluence zone for the scenario $5\left(Q_{\text {Sarine }}=175 \mathrm{~m}^{3} / \mathrm{s} / Q_{\text {Gerine }}=2 \mathrm{~m}^{3} / \mathrm{s}\right)$. 
formed by the bar imposes a course change of the Sarine River bed. For comparison, the discharge of $175 \mathrm{~m}^{3} / \mathrm{s}$ was exceeded every year before the construction of the Rossens Dam.

\section{CONCLUSIONS}

The confluence of two channels, each of them having independent flow and sediment discharge regimes creates complex erosional and depositional conditions. Changing these input conditions can provoke important changes in channel morphology at the confluence.

The Rossens Hydrolelectric Scheme, constructed in 1948 significantly influences the hydrology of the Sarine River. This is a key element for explaining the morphological processes, especially the large erosion at the left bank occurred at the confluence between the Sarine and the Gerine Rivers over the last years.

Simplified numerical simulations have shown that the minimum discharge of the Sarine to transport the material annually deposited at the confluence by the Gerine is around $175 \mathrm{~m} / \mathrm{s}$. This discharge is slightly lower than the peak value of the 2-year return period flood, determined after the construction of the Rossens Dam. The imbalance between the sediment transport frequencies on the two confluents has been responsible for the morphological changes occurred in the confluence since the construction of the dam.

\section{REFERENCES}

Benda, L., Poff, N.L., Miller, D., Dunne, T., Reeves, G., Pess, G. and Pollock, M. 2004. The network dynamics hypothesis: How channel networks structure riverine habitats, BioScience, 54, 413-427.

Best, J.L. 1988. Sediment transport and bed morphology at river channel confluences, Sedimentology, $35,481-498$

Boyer, C., Roy, A.G. and Best, J. 2006. Dynamics of a river channel confluence with discordant beds: Flow turbulence, bed load sediment transport, and bed morphology. Journal of Geophysical Research, 111: F04007 1_22.

Fehr, R. 1987. Einfache bestimmung der korngrössenverteilung von geschiebematerial mit Hilfe der Linienzahlanalyse. Schweizer Ingenieur und Architekt, 38:1103-1109, 1987. (in German).

Kenworthy, S.T., and Rhoads, B.L. 1995. Hydrologic control of spatial patterns of suspended sediment concentration at a stream confluence, Journal of Hydrology, 168, 251-263.

Leite Ribeiro, M., Blanckaert, K., Roy, A.G. and Schleiss, A.J. 2012a. Flow and sediment dynamics in channel confluences. Journal of Geophysical Research —Earth Sciences, doi:10.1029/2011 JF002171.

Leite Ribeiro, M., Blanckaert, K., Roy, A.G. and Schleiss, A.J. 2012b. Hydromorphological implications of local tributary widening for river rehabilitation. Water Resources Research, 48(10).

Mivelaz, L. 2005. Augmentation du débit de dotation de la Petite Sarine en aval du barrage de Rossens, 2005. Entreprises Electriques Fribourgeoises, Direction Production Energie. Available at http://lch. epfl.ch/.

Rhoads, B.L., Riley, J.D., and Mayer, D.R. 2009. Response of bed morphology and bed material texture to hydrological conditions at an asymmetrical stream confluence, Geomorphology, 109, 161-173.

Ribi, J-M. 2000. Aménagement de la Gérine-Mesures de protection contre les crues. Ribi SA. Report not published. (in French).

Rice, S.P., Kiffney, P., Greene, C. and Pess, G.R. 2008. The Ecological Importance of Tributaries and Confluences, 209-242 pp., John Wiley \& Sons, Ltd.

Shields, I.A., 1936, Anwendung der Ähnlichkeitsmechanik und der Turbulenzforschung auf die Gescheibebewegung, Mitt. Preuss Ver-Anst., 26 (in German).

Wampfler, S. 2008. Morphologie des confluences naturellement aménagées-Etude de terrain d'une confluence naturelle et étude expérimentale sur une confluence en modèle, edited, p. 211, Master Project. Laboratory of Hydraulic Constructions ( $\mathrm{LCH}$-Ecole Polytechnique Fédérale de Lausanne $(E P F L)$ (in French). 